\title{
Coğrafya Tahayyülleri: Ulusal Kimlik, Anlatı ve Sınır*
}

\section{Imagining Geography: National Identity, Narrative and Bordering}

\author{
Bilal Görentaş ${ }^{\text {a,** }}$ \\ ${ }^{a}$ Dr. Öğr. Üyesi, Kilis 7 Aralık Üniversitesi, Fen Edebiyat Fakültesi, Coğrafya Bölümü, 79000, Kilis/Türkiye. \\ ORCID: 0000-0002-6802-5007
}

\section{MAKALE BILGIISI}

\section{Makale Geçmişi:}

Başvuru tarihi: 26 Aralık 2017

Düzeltme tarihi: 06 Ocak 2018

Kabul tarihi: 10 Ocak 2018

\section{Anahtar Kelimeler:}

Ulusal Kimlik

Anlatı

Sinır

Coğrafya

\section{ART ICLE INFO}

\section{Article history:}

Received 26 December 2017

Received in revised form 06 January 2018

Accepted 10 January 2018

\section{Keywords:}

National Identity

Narrative

Bordering

Geography
ÖZ

Bu çalışma, birbiriyle bağlantılı üç araştırma alanı olan ulusal kimlik, anlatı ve sınır arasındaki iliş̧ileri incelemektedir. Bu üç kavram coğrafyanın üretimi ve yeniden inşası için elzemdir. $\mathrm{Bu}$ çalışma bu üç kavramı tanıtıp, bunlar arasındaki bağlantıları ortaya çıkarmakta ve bu şekilde ulusal kimliklerin sınır ve anlatı kavramları ile ilişkili bir şekilde anlaşılması ve çalışılması için kavramsal bir çerçeve çizmektedir. Ayrıca ulusal kimliklerin tarihsel olarak modern yapılar olduğu, anlatılar ile oluşturulduğu, içselleştirildiği, çoklu ve sürekli değişim halinde olduğu ileri sürülmektedir. $\mathrm{Bu}$ nedenle anlatı ve söylem kavramları bu kimliklerin üretimi ve yeniden inşası için gereklidir. Bu makale, aynı zamanda ulusal kimliklerin doğrudan sınır kurumu ile ilgili olduklarını savunmaktadır. Sınır kurumu kavramından kastedilen bir coğrafya üzerine çizilmiş fiziksel bir çizgi veya bir tel örgü değil, sosyal ve mekânsal benzerlik ve farklılaşmaların oluştuğu bir süreçtir. Bu kimliklere anlam veren işte bu sınır kurumu sürecidir.

\section{A B S T R A C T}

This paper explores the relationships between three interconnected research domains: national identity, narrative and border. These three concepts are crucial to produce and re-produce geography. This paper introduces these three concepts and explores how they are connected to each other, in order to draw a conceptual framework to understand and study national identities in relation to borders and narratives. The paper argues that national identities are historically modern constructs produced through narratives, internalised, multiple and subject to change. Narratives and discourses are significant to produce and reproduce these identities. Thus, narratives and identities are interdependent. This paper also argues that national identities are directly related to borders. By border concept, this paper does not only refer to a physical line or fences on space, but bordering as a process through which social and spatial homogenisations and differentiations occur. It is this bordering process that gives significance to identities.

\section{Introduction}

Geographies are being made through drawing borders on space and attributing identities to these bounded spaces by producing and circulating on-going narratives about them. This paper focuses on these connections between bordering, identity and narrative.

The paper consists of a threefold argument about the interrelationship between national identities, narratives and borders. It starts with some theoretical assumptions about identities, particularly national identities, in order to draw a conceptual framework to understand and study national identities in relation to borders and narratives. The second section focuses on the significance of narratives and discourses in the construction of national identities. Finally, the paper outlines the connections between bordering and identity in order to provide some valuable insights into this interconnected research domain. This paper argues that national identities are modern constructs, produced through specific discursive formations and internalised by their members. National identities are being constantly produced, multiple and continually evolving. It also argues that there

\footnotetext{
* Bu çalışma, 2016 yılında University of Southampton tarafından kabul edilen "Nation, bordering and identity on the border between Turkey and Iraq" adlı Doktora tezinden türetilmiştir.

** Sorumlu yazar/Corresponding author.

e-posta: bilal.gorentas@kilis.edu.tr
} 
are always narratives of nations through which national identities are constructed. Hence, these narratives and discourses are at the core of national identities. The paper, finally, explores the interconnected processes between bordering and identity building.

\section{National Identities: Theoretical Assumptions}

The concepts of nation and identity have always been controversial to researchers. There is a wide range of understandings of these concepts in the literature. In order to provide a clearer perspective to understand and study these concepts, this section outlines some key features of these concepts. In this paper, a nation is understood as a historically modern human community who share some perceptions of sameness and/or similar political interests and feelings of belongings to each other and to a territory. To draw a conceptual framework, six theoretical assumptions have been deducted from a wide range of literature on nation and identity.

First of all, national identities are historically modern phenomena (Hobsbawm, 1992). Nations are not natural, primordial and not even biological; but historically contingent modern constructs and are 'imaginary' (Anderson, 1991). There are three main approaches to the concept of nation in the literature: primordialist, ethnosymbolist and modernist. Primordialist claims that nations are based on some 'objective' factors, such as gene, language, history and territory. Thus, the primordialist approach is based on the perceptions that nations are given, unchangeable basic human categories. However, the truth is that there is no biologically pure race, a distinct language or an objective history. Hence, this approach fails to explain what a nation is and how the national borders are drawn. Ethno-symbolist approach combines these 'objective' factors with some 'subjective' ones, such as perception, sentiment and attitudes. It argues that nations are based on these 'objective' features with added modern symbols and myths. Therefore, they give special attention to 'myths and symbols' in order to explain how past 'ethnies' become nations (Smith, 1986: 15-16). To become a nation an 'ethnie' must undergo many changes which transform its structure and mentality; and throughout this process it absorbs many alien elements and a never-ending flux of influences from other cultures (Özkirimli, 2003). Hence, It can be accepted that nationalists use the myths and symbols of the past to build a national identity yet it is very difficult to evaluate their impact on nation building since in many cases nationalists invent these myths. Finally, modernists approach the term nation as a complete modern construct. It does not mean that there was no race or language or any culture. There were definitely many pre-existing cultures and languages. However, they were 'often subtly grouped, shading into each other, overlapping, intertwined; there exist, usually but not always, political units of all shapes and sizes' (Gellner, 2006: 47). What nationalism does is to use these pre-existing cultures and to transform them radically into nations. Histories are created, common languages are constructed, traditions are invented and racial purities are restored.

Secondly, national identities are 'produced in specific historical and institutional sites within specific discursive formations and practices by specific strategies' (Hall, 1996: 4). There is always the narrative of the nation that is constantly told in national histories, literature, media, popular culture and thus it is embedded into society (Hall, 1992: 623). There is an emphasis on origins, continuity, tradition and timelessness in these narrations. These provide stories for these 'imagined communities' in which each member can picture oneself as a part of whole (Anderson, 1991). Hence, this imagined community becomes a reality in the realm of this discourse launched by politicians and intellectuals and disseminated through the system of education, media, military etc. (Hall, 1992: 623).

Thirdly, national identities are internalised and taken for granted. Although, national identities are modern discursive products, they have been naturalised and thus become a dominant source of meanings for the identity constructions of the self. In this sense, national identities can be viewed as sort of 'habitus'. 'Habitus' is understood as certain beliefs that become part of society's natural structure (Bourdieu, 1990). In other words, 'as a complex of common ideas, concepts or perception schemes, (a) of related emotional attitudes inter-subjectively shared within a specific group of persons; (b) as well as of similar behavioural dispositions; (c) all of which are internalised through 'national' socialisation' (De Cillia et al., 1999: 153). Although national identities are discursively constructed, they become real and natural. They can generate strong senses of belongings, attachments and sentiments. National identities are being considered as if they are an essential part of one's nature.

Fourthly, national identities are constantly being produced and re-produced through different ways of inclusions and exclusions. They are not just about constructing 'us'; but also constructing 'others'. As Hall (1996: 3) states, identity requires a 'constitutive outside' to be constructed. Therefore, constructing an identity needs excluding something. In this sense, construction of a national identity is an act of power. It is because the discourse that generates the stories of inclusion and exclusion are produced through power.

Fifthly, national identities are multiple. There is not one single national identity for all in any essentialist sense; but different identities constructed through different discourses according to context (Hall, 1996: 4).

Finally, national identities are always subject to change. They are discursively produced, thus flexible processes and constantly evolving. They are not fixed entities that remain the same always (De Cillia et al., 1999: 154). They are continually re-produced and re-negotiated; therefore, any analysis of an identity would represent just 'a snapshot of the unfolding processes' (Meinhof and Galasinski, 2005: 8). Any analysis of identity construction would only represent the identity construction of that specific time in that place, rather than a universal and permanent one.

\section{Narratives and Identity}

'In the end, we become the autobiographical narratives by which we "tell about" our lives' (Bruner, 2004: 694)

The assumptions listed above suggest a conceptual framework that functions as an analytical tool through which national identities can be explored. Among all, this conceptual framework indicates the centrality of discourse 
and narratives in the constructions and negotiations of national identities. It is argued that national identities are 'constructed', rather than inherited, through discourses and narratives. National identities are 'produced' by positioning the self or by being positioned in the narrative of the nation. A self is rather being 'thrown' into these narratives (Benhabib, 2002: 15). As Somers (1994: 606) puts it: 'all of us come to be who we are (however ephemeral, multiple, and changing) by being located or locating ourselves (usually unconsciously) in social narratives rarely of our own making'.

The links between narratives and identity are ontological and interdependent. As Somers and Gibson (1993: 30) state that 'the relationship between narrative and ontology is processual and mutually constitutive'. Arendt (1998: 184) states that 'every individual life can eventually be told as a story'. Each life story began with inserting itself into the human world. Arendt (1998: 183) defines the realm of human affairs as 'web of relationships'. Construction of identity consists of positioning oneself in this existing web, through 'speech' and 'act'. Taylor (1989: 36) defines these relations between identity and language with the concept of 'web of interlocution': 'I am a self only in relation to certain interlocutors: one way in relation to those conversation partners which are essential to my achieving self-definition; in another in relation to those who are now crucial to my continuing grasp of languages of self-understanding-and, of course, these classes may overlap. A self exists only within what I call 'webs of interlocution'. Benhabib (2002) states that 'we become aware of who we are by learning to become a conversation partner in these narratives'.

Human communication consists also of conveying who one is, where one's belongings, loyalties and attachments are (De Fina, 2011). Arendt (1998: 181) states that 'the moment we want to say 'who' somebody is, our very vocabulary leads us astray into saying 'what' one is... we begin to describe a type or a 'character'. The disclosure of the specific uniqueness of an individual, the question of 'who' rather than 'what' one is, is in everything one says and does (Arendt, 1998). As Taylor (1989: 52) puts it: we must inescapably understand our lives in narrative forms. The narrator of a story 'tell us more about their subjects, the 'hero' in the centre of each story, than any product of human hands ever tells us about the master who produced it' (Arendt, 1998: 184). The only 'one' a story reveals is its 'hero'. Who the narrator is can only be known if the narrator is the hero in the story, in narrator's biography (Arendt, 1998). As also quoted above 'in the end, we become the autobiographical narratives by which we "tell about" our lives (Bruner, 2004: 694).

Narratives, thus, become the prime tools in search of identities. Giddens (1991: 54) states that 'a person's identity is not to be found in behaviour, nor - important though this is - in the reactions of others, but in the capacity to keep a particular narrative going. The individual's biography, if she is to maintain regular interaction with others in the day-today world, cannot be wholly fictive. It must continually integrate events which occur in the external world, and sort them into the ongoing 'story' about the self'. For Giddens (1991: 53), a self's identity is not a set of traits or characteristics but a self's own reflexive understanding of their identity, a self's narratives.
It is, thus, important to focus on the narratives through which a self discloses his/her identity, self-understandings, attachments and belongings. It is also important to note that analysing these narratives require at all times an understanding of the socio-political contexts of the narrator.

\section{Bordering and Identity}

Borders are related to identities. As Balibar (2002: 76) states 'to mark out a border is to define a territory, to delimit it, so to register the identity of that territory, or confer one upon it'. Drawing borders is not only about creating a bounded space, but also about producing a social collectiveness. Similarly, constructing an identity is a process of defining a group's boundaries and borders (Barth, 1998). As Bourdieu and Thompson (1991: 120) state 'to institute, to give a social definition, an identity, is also to impose boundaries'. Constructing borders is not only about drawing lines or building fences in physical landscapes but also about the processes through which social and spatial categories and differentiations occur (Newman, 2006). Hence, bordering and identity building are interdependent processes.

Space is understood as a social product (Lefebvre, 1991:26). Geographies, just like history, are made by people (Said, 1979). As Barth (1998) articulates every society creates/defines its space in order to create itself. Making geographies is about creating territories by drawing borders. Sack (1986: 1) defines territoriality as 'spatial strategy to affect, influence, or control resources and people, by controlling area'. Borders, for geographers, are firstly expression or manifestation of the territoriality of states (Newman and Paasi, 1998). It is the territoriality that gives meaning and significance to borders.

Territorial borders have both material and symbolic uses. In a sense, they are real and have physical presence. Their effects are real and, as Agnew (2008: 176) argues, they 'trap thinking about and acting in the world in territorial terms'. In another sense, they are imaginary lines on the ground with symbolic meanings. Material dimensions of a territory are endowed with imaginative values which stem from a range of social, cultural and political meanings (Bachelard, 1994). These given meanings are sometimes more important than material space itself. They are 'the justified borders of ours': 'We are also forced or persuaded to learn what are the legitimate and hegemonic national meanings attached to these borders and what are the pools of emotions, fears and memories that we have to draw on in this connection' (Paasi, 2011: 24). The meanings and the pools of emotions attached to national borders are disseminated deeply into society through various ways. Paasi (2011: 24) defines these pools of meanings as 'emotional landscapes of control'. Borders are the edges of these 'imagined geographies' (Said, 1979); and these meanings and emotions associated with borders play a key role in the construction of identities and the sense of belonging to 'imagined communities' (Anderson, 1991).

The relations between borders and identity are permanent processes. Borders are a specific form of institutions and symbols that simultaneously produce distinctions between social groups and are produced by them (Paasi, 1998). Yet, it does not mean that borders as institutions and symbols are stable entities; instead they are perpetually developing and being transformed, so they are the discursive constitutive of 
collective identities. Bordering as a process is also about the complex, perpetually on-going, hegemonic nation-building (Paasi, 2012). As Hall (1992: 4) states that 'Identities are never unified and, in late modern times, increasingly fragmented and fractured; never singular but multiply constructed across different, often intersecting and antagonistic, discourses, practices, and positions. They are subject to a radical historicisation, and are constantly in the process of change and transformation'.

Borders, by definition, are about creating and taking sides, which construct many more associated dichotomies: insideoutside, we-they, inclusion-exclusion, us-other. These dichotomies are the result of the social process of a continuous defining of 'self' and 'other'. Constructing or identifying the 'difference' is directly linked to drawing borders. 'Others' and 'us' are equally important for the formation of borders and therefore constantly produced and reproduced. Borders are constructed through different ways of inclusions and exclusions. They are not just about constructing 'us'; but also constructing 'others'. As Hall (1996:4) states 'it is only through the relation to the Other, the relation to what it is not, to precisely what it lacks, to what has been called its constitutive outside that the 'positive' meaning of any term - and thus its 'identity' - can be constructed'.

As stated above, state borders have double-edged significance; while they signify power, control and exclusion, they simultaneously stand for empowerment and inclusion. It is not only about 'differentiation' but also 'homogenisation'. An important challenge in border studies is therefore to analyse how the exclusions and inclusions between 'us' and 'others' that a border implies are historically and discursively constructed and shaped in relation to power. Borders are the expression of power relations; and manifest themselves in social (economic, cultural and political) practices and discourses that directly involve the production and reproduction of identities. Meanings attached to borders and identities are constantly evolving through these various social, political and discursive practices. Therefore, the meanings of a border can be analysed through these social practices and discourses in which identities are produced and reproduced in relation to power. Hall (1992: 4) states that identities are 'produced in specific historical and institutional sites within specific discursive formations and practices, by specific enunciative strategies'. Somers and Gibson (1993: 5) states that all people come to be who they are by locating themselves or being located in social narratives, which are rarely of their own making.

\section{Conclusion}

This paper has provided valuable insights into the relationships between three interconnected research domains: national identity, narrative and borders. These concepts have crucial importance in understanding of the production of geography. The paper introduced these relationships in order to provide a conceptual framework to understand and study national identities in relation to borders and narratives.

The paper initially reviewed six main assumptions related to national identities that are deducted from a wide range of literature. It argued that national identities are historically modern constructs and produced through specific discursive formations. Although national identities are considered as modern discursive products, they are taken from granted and internalised. It is also argued that national identities are not only about constructing 'us' but also about constructing 'other'. Finally, national identities do not have any essence that is shared by all their members, but are multiple and always subject to change. Thus, national identities are constantly unfolding processes.

Secondly, this paper investigated the connection between identity and narrative. It is argued that narratives and identities are interdependent. National identities are being produced and re-produced by positioning oneself in the narratives of the nations or by being positioned in these narratives. Thus, narratives are the prime tools in the exploration of national identities. It is the narratives through which a self discloses his/her identity, self-understandings, attachments and belongings.

Finally, this paper focused on the connections between bordering and identity. Bordering and identity building are understood as interdependent processes that are constantly evolving. The relations between border and identity are permanent processes. Bordered space is filled with symbolic meanings and emotions that are disseminated deep into society by various ways. Identity building is also a constant process. The constructions of 'other' and 'us' are equally important in the constructions of borders and identity.

\section{References}

Agnew, J. (2008). Borders on the mind: re-framing border thinking. Ethics \& Global Politics, 1(4), 175-191.

Anderson, B. (2006). Imagined communities: Reflections on the origin and spread of nationalism. London: Verso Books.

Arendt, H. (1998). The Human Condition. USA: University of Chicago Press.

Bachelard, G. (1994). The Poetics of Space. Boston: Beacon Press.

Balibar, E. (2002). Politics and the Other Scene. London: Verso Books.

Barth, F. (1998). Ethnic Groups and Boundaries: The Social Organization of Culture Difference. USA: Waveland Press.

Benhabib, S. (2002). The claims of culture: Equality and diversity in the global era. New Jersey: Princeton University Press.

Bourdieu, P. (1990). Structures, habitus, practices. The logic of practice, 52-65.

Bourdieu, P., \& Thompson, J. B. (1991). Language and Symbolic Power. USA: Harvard University Press.

Bruner, J. (2004). Life as narrative. Social Research, 71(3), 691-710.

De Cillia, R., Reisigl, M., \& Wodak, R. (1999). The discursive construction of national identities. Discourse \& Society, 10(2), 149-173. 
De Fina, A. (2011). Discourse and identity. In: T. A. Van Dijk (Ed.), Discourse studies: A multidisciplinary introduction. London: SAGE Publications.

Gellner, E. (2006). Nations and Nationalism. Oxford: Blackwell Publishing.

Giddens, A. (1991). Modernity and Self-Identity: Self and Society in the Late Modern Age. California: Stanford University Press.

Hall, S. (1992). The question of cultural identity. In: S. Hall, C. Nelson \& P. Treichler (eds.), Modernity and Its Futures, (s. 595-635). Oxford: Polity Press.

Hall, S. (1996). Who needs identity. Questions of cultural identity, 16(2), 1-17.

Hobsbawm, E. J. (1992). Nations and Nationalism Since 1780: Programme, Myth, Reality. UK: Cambridge University Press.

Lefebvre, H. (1991). The production of space (Vol. 142). Oxford: Blackwell Publishing.

Meinhof, U. H., \& Galasinski, D. (2005). The language of belonging. In: The Language of Belonging (pp. 13-49). London: Palgrave Macmillan.

Newman, D. (2006). The lines that continue to separate us: borders in our 'borderless' world. Progress in Human Geography, 30(2), 143-161. http://dx.doi.org/10.1191/0309132506ph599xx

Newman, D., \& Paasi, A. (1998). Fences and neighbours in the postmodern world: boundary narratives in political geography. Progress in Human Geography, 22(2), 186207. http://dx.doi.org/10.1191/030913298666039113

Özkirimli, U. (2003). The nation as an artichoke? A critique of ethnosymbolist interpretations of nationalism. Nations and Nationalism, 9(3), 339-355. http://dx.doi.org/10.1111/1469-8219.00100

Paasi, A. (1998). Boundaries as social processes: Territoriality in the world of flows. Geopolitics, 3(1), 6988. http://dx.doi.org/10.1080/14650049808407608

Paasi, A. (2011). A border theory: an unattainable dream or a realistic aim for border scholars?. In: Wastl-Walter, D. (Ed.), The Ashgate Research Companion to Border Studies, (pp. 11-31). London: Routledge.

Paasi, A. (2012). Border studies reanimated: going beyond the territorial/relational divide. Environment and Planning A, 44(10), 2303-2309. http://dx.doi.org/10.1068/a45282

Sack, R. D. (1986). Human Territoriality: Its Theory and History. UK: Cambridge University Press.

Said, E. W. (1979). Orientalism. New York: Vintage.

Smith, A. D. (1986). The Ethnic Origins of Nations. Oxford: Blackwell Publishing.

Somers, M. R. (1994). The narrative constitution of identity: A relational and network approach. Theory and society, 23(5), 605-649.

Somers, M. R., \& Gibson, G. D. (1993). Reclaiming the epistemological other: narrative and the social constitution of identity. CSST Working Papers. WP No: 94. USA: University of Michigan

Taylor, C. (1989). Sources of the self: The making of the modern identity. UK: Cambridge University Press. 